\title{
Effect of $\pi$-Conjugated Spacer in N-Alkylphenoxazine-Based Sensitizers Containing Double Anchors for Dye-Sensitized Solar Cells
}

\author{
Yung-Sheng Yen * $*$ and Velu Indumathi
}

Citation: Yen, Y.-S.; Indumathi, V.

Effect of $\pi$-Conjugated Spacer in

N-Alkylphenoxazine-Based

Sensitizers Containing Double Anchors for Dye-Sensitized Solar Cells. Polymers 2021, 13, 1304 https://doi.org/10.3390/ polym13081304

Academic Editor: Vessela Tsakova

Received: 17 March 2021

Accepted: 14 April 2021

Published: 16 April 2021

Publisher's Note: MDPI stays neutral with regard to jurisdictional claims in published maps and institutional affiliations.

Copyright: (C) 2021 by the authors Licensee MDPI, Basel, Switzerland. This article is an open access article distributed under the terms and conditions of the Creative Commons Attribution (CC BY) license (https:// creativecommons.org/licenses/by/ $4.0 /)$.
Center for Nanotechnology, Department of Chemistry, Chung Yuan Christian University, Zhongli 32023, Taiwan; indumathichemstry@gmail.com

* Correspondence: ysyen@cycu.edu.tw; Tel.: +886-3-2653327

\begin{abstract}
A series of novel double-anchoring dyes for phenoxazine-based organic dyes with two 2-cyanoacetic acid acceptors/anchors, and the inclusion of a 2-ethylhexyl chain at the nitrogen atom of the phenoxazine that is connected with furan, thiophene, and 3-hexylthiophene as a linker, are used as sensitizers for dye-sensitized solar cells. The double-anchoring dye exhibits strong electronic coupling with $\mathrm{TiO}_{2}$, provided that there is an efficient charge injection rate. The result showed that the power conversion efficiency of DP-2 with thiophene linker-based cell reached $3.80 \%$ higher than that of DP-1 with furan linker $(\eta=1.53 \%)$ under standard illumination. The photovoltaic properties are further tuned by co-adsorption strategy, which improved power conversion efficiencies slightly. Further molecular theoretical computation and electrochemical impedance spectroscopy analysis of the dyes provide further insight into the molecular geometry and the impact of the different $\pi$-conjugated spacers on the photophysical and photovoltaic performance.
\end{abstract}

Keywords: phenoxazine; dye-sensitized solar cells; sensitizers

\section{Introduction}

Dye-sensitized solar cells (DSSCs) have cultivated a huge interest owing to its ease of fabrication and low cost since the report by Grätzel et al. in 1991 [1]. They imitate natural photosynthesis by means of a molecular absorber, which transforms light into electrical energy [2]. The high power conversion efficiencies of $13.0 \%, 11.50 \%$, and $12.5 \%$ has been reached for porphyrin- [3], polypyridyl Ru(II) complex- [4], and metal-free organic dye-based [5] DSSCs, correspondingly. Many current reports are seen that suggest metal free organic sensitizers might have power conversion efficiency (PCE) cell efficiencies cheaply with that of Ru-based DSSCs [6]. Although Ru-based complexes maintain the record of validated efficiency of over $11 \%$, the Ru-based dyes are costly and environmental unfriendly. Compared to the Ru dyes, metal-free organic dyes have more than a few favors: (i) they take greater molar extinction coefficients; (ii) simple synthesis; (iii) lower cost and more flexible in molecular design. As such, metal-free dyes are also considered hopeful for applications in DSSCs, and several organic dyes has been used as the sensitizers of DSSCs [7-11]. Besides dye-sensitized solar cells, development of new technologies with renewable energy (e.g., sunlight) for the production of $\mathrm{H}_{2}, \mathrm{CO}, \mathrm{CH}_{4}$ solar fuels for fuel cell applications also have attracted attention, since they help effective reductions of energy shortage and environment pollution [12,13].

Organic sensitizers usually construct with a $\mathrm{D}-\pi-\mathrm{A}$ structure configuration, comprising of a donor $(\mathrm{D})$, a $\pi$-linker $(\pi)$, and an acceptor $(\mathrm{A})$, which also functions as the anchor. The heteroaromatic rings such as thiophene and furan that have been demonstrated to be useful for red shifting of the absorption wavelength were widely used as $\pi$-conjugated spacers in sensitizers. Furan also has lower resonance energy than thiophene, which would favor formation of the quinoid structure during intramolecular charge transfer. For example, Hua et al. reported the benzotriazole-based sensitizers containing furan moiety 
for DSSCs applications, and the result shows that the dyes containing furan moiety as spacers can improve the device efficiency and long-term stability [14]. Anchoring groups also play an important role whether on electron injection or bonding on the $\mathrm{TiO}_{2}$ surface [15]. Traditionally, the most commonly used anchors in DSSCs are carboxylic acid and cyanoacrylic acid groups [16]. Subsequently, in the recent exponent development of DSSCs research, various new anchors have occurred and have been tried, that has expressively increased the choice of variable materials, and facilitates awareness of DSSCs. Previously, we developed a sequence of two-anchored organic sensitizers based on imidazole with moderate solar cell performance [17]. We found that they truly not only efficiently inhibited dark current, but also led to excited-state quenching and hindered electron injection. Development of organic dye with di- or multi anchor groups displayed not only enhanced optical properties, but also an increase of electron extraction paths compared to those of dyes with a single anchor. For example, Kumar et al. designed and synthesized a dihydrophenazine dye with two anchor groups recently [18]. In this case, the result shows that dihydrophenazine dye with double-anchors inhibits the aggregation on $\mathrm{TiO}_{2}$ and thus reduces the charge recombination. Zhang et al. reported a series of phenothiazine dye with five anchors, and the result displayed that increasing the number of electron acceptors in the backbone of dyes can improve the light-harvesting ability, electrochemical properties, and suppress dark current [19]. Normally, dyes with two acceptors, $\mathrm{D}(-\pi-\mathrm{A})_{2}$, make it [20-22], or might not [23,24], show more efficient dark current suppressing than their $\mathrm{D}-\pi-\mathrm{A}$ relative. Consequently, photocurrents can be increased.

Among various electron donors, besides the use of triphenylamine as a donor for sensitizers, phenothiazine and phenoxazine electron donor units featuring unique electronic and optical properties have been introduced into a push-pull organic dye which exhibits promising efficiency. Recently, Liu et al. reported a series of dyes based on thieno $[2,3-f]$ benzofuran $(\mathrm{BDF})$, by the incorporation of several donors from triphenylamine, carbazole, and phenothiazine [25]. Among these dyes, employing phenothiazine as a donor showed the highest open-circuit voltage $\left(V_{\mathrm{OC}}\right)$, short-circuit photocurrent density $\left(J_{\mathrm{SC}}\right)$, and PCE. Phenothiazine has the strongest electron-donating property, which improves the light-harvesting ability of the dye and effectively suppresses the dark current. We similarly found the substituents at the nitrogen atom of phenothiazine-cored dyes of the $\left(D(-\pi-A)_{2}\right)$ ( $\mathrm{D}=$ phenoxazine) kind have a profound effect on the cell performance $[6,21,26]$, such as light-harvesting, dye aggregation, and dark current, and the maximum cell efficiency was compared with that of the N719-based standard cell. Hence, there are a growing number of reports on dyes with two-anchoring groups in fresh years [27-33]. These $\mathrm{D}(-\pi-\mathrm{A})_{2}$ dyes show an interesting phenomenon that not only displays better light-harvesting ability but also provides efficient electron extraction compared to the congeners with only one anchor. Phenoxazine shows similar structural and electrochemical properties to phenothiazine, which implies that phenoxazine could also be incorporated as a dye sensitizer. With our continuing interest in metal-free sensitizers for DSSC applications, we decided to incorporate the phenoxazine moiety in the conjugation spacer of the dye.

Herein, we report new phenoxazine-based sensitizers with two anchors and used as sensitizers for dye-sensitized solar cells. In this present work, $\mathrm{D}(-\pi-\mathrm{A})_{2}$ type di-anchoring dyes based on phenoxazine central core with different $\pi$-conjugated spacers were synthesized and for dye-sensitized solar cells application. The photophysical properties of the DP compounds and the performance of the DSSCs fabricated from these three dyes are also discussed.

\section{Materials and Methods}

\subsection{General Method}

All chemicals commercially available, starting materials and solvents, were purchased from Aldrich (St. Louis, MO, USA), TCI (Tokyo, Japan) or Acros Co. (Fukuoka, Japan), and used as received. Solvents THF, toluene, and diethyl ether were distilled under a 
nitrogen atmosphere with sodium and benzophenone. Other chemicals were bought and used without further purification.

The ${ }^{1} \mathrm{H}$ NMR and ${ }^{13} \mathrm{C}$ spectra were recorded using a Bruker Advance NMR $300 \mathrm{~Hz}$ spectrometer with $\mathrm{CDCl}_{3}$ and DMSO- $\mathrm{d}_{6}$ that were purchased from Cambridge Isotope Laboratories Inc. (Tewksbury, MA, USA). Absorption spectra were recorded on a JASCO V-730 probe UV - vis spectrophotometer. All chromatographic separations were carried out on silica gel (45-75 um mesh). Mass spectra (FAB) were verified on a Micro TOF-II mass spectrometer.

The photoelectrochemical characterizations on the solar cells were carried out using an Oriel Class AAA solar simulator (Oriel 94043 A, Newport Corp., Irvine, CA, USA). Photocurrent-voltage characteristics of the DSSCs were recorded with a potentiostat/galvanostat (CHI650B, CH Instruments, Inc., Bee Cave, TX, USA) at a light intensity of $100 \mathrm{mWcm}^{-2}$ calibrated by an Oriel reference solar cell (Oriel 91150, Newport Corp., Irvine, CA, USA). The monochromatic quantum efficiency was recorded through a monochromator (Oriel 74100, Newport Corp., Irvine, CA, USA) at short circuit condition. The intensity of each wavelength was in the range of 1 to $3 \mathrm{mWcm}^{-2}$. Electrochemical impedance spectra (EIS) were recorded for DSSCs in the dark at $-0.65 \mathrm{~V}$ potential at room temperature, whose frequency travelled ranged from $10 \mathrm{mHz}$ to $100 \mathrm{kHz}$.

\subsection{Fabrication of DSSCS}

The photoanode used was the $\mathrm{TiO}_{2}$ thin film $(12 \mu \mathrm{m}$ of $20 \mathrm{~nm}$ particles as the absorbing layer and $6 \mu \mathrm{m}$ of $100 \mathrm{~nm}$ particles as the scattering layer) coated on FTO glass substrate with a dimension of $0.5 \times 0.5 \mathrm{~cm}^{2}$, and the film thickness measured by a profilometer (Dektak3, Veeco/Sloan Instruments Inc., Santa Barbara, CA, USA). A platinized FTO produced by thermopyrolysis of $\mathrm{H}_{2} \mathrm{PtCl}_{6}$ was used as a counter electrode. The $\mathrm{TiO}_{2}$ thin film was dipped into the THF solution containing $3 \times 10^{-4} \mathrm{M}$ dye sensitizers for at least $12 \mathrm{~h}$. For the co-adsorbed solar cell, chenodeoxycholic acid (CDCA) was added into the dye solutions at a concentration of $10 \mathrm{mM}$. After rinsing with THF, the photoanode, adhered with a polyimide tape of $30 \mu \mathrm{m}$ in thickness and with a square aperture of $0.36 \mathrm{~cm}^{2}$, was placed on top of the counter electrode and tightly clipped them together to form a cell. A $0.6 \times 0.6 \mathrm{~cm}^{2}$ of cardboard mask was clipped onto the device to constrain the illumination area. An electrolyte was then injected into the space and then the cell was sealed with the Torr Seal cement (Varian, MA, USA). The electrolyte was composed of $0.5 \mathrm{M}$ lithium iodide (LiI), $0.05 \mathrm{M}$ iodine $\left(\mathrm{I}_{2}\right)$, and $0.5 \mathrm{M}$ 4-tert-butylpyridine that was dissolved in acetonitrile.

\subsection{Quantum Chemistry Computation}

Q-Chem 4.0 software was used for the computations. $B_{3} L Y P / 6-31 G^{*}$ basis set was used for geometry optimization of the molecules. For each molecule, a number of possible conformations were examined and the one with the lowest energy was used. The same function was also applied for the calculation of excited states using time-dependent density functional theory (TD-DFT). There exist a number of previous works that employed TD-DFT to characterize excited states with charge-transfer character. In some cases, underestimation of the excitation energies was seen. Therefore, in the present work, we use TD-DFT to visualize the extent of transition moments as well as their charge-transfer characters, and avoid drawing conclusions from the excitation energy.

\subsection{Synthesis}

All the new dyes were prepared via Knoevenagel condensation reaction by reacted corresponding aldehyde derivatives and cyanoacetic acid in the presence of the catalytic amount of ammonium acetate.

(2E,2'E)-3,3'-(5,5'-(10-(2-ethylhexyl)-10H-phenoxazine-3,7-diyl)bis(furan-5,2-diyl))bis (2-cyanoacrylic acid) (DP-1). Spectroscopic data for DP-1: ${ }^{1} \mathrm{H}$ NMR $\left(400 \mathrm{MHz}, \mathrm{THF}-\mathrm{d}_{8}\right): \delta$ $7.93(\mathrm{~s}, 2 \mathrm{H}), 7.47(\mathrm{~d}, J=8.0 \mathrm{~Hz}, 2 \mathrm{H}), 7.35(\mathrm{~d}, J=3.2 \mathrm{~Hz}, 2 \mathrm{H}), 7.22(\mathrm{~s}, 2 \mathrm{H}), 6.97(\mathrm{~d}, J=4.0 \mathrm{~Hz}$, $2 \mathrm{H}), 6.83(\mathrm{~d}, J=8.0 \mathrm{~Hz}, 2 \mathrm{H}), 3.64(\mathrm{~d}, J=7.2 \mathrm{~Hz}, 2 \mathrm{H}), 1.96-1.89(\mathrm{~m}, 1 \mathrm{H}), 1.46-1.29(\mathrm{~m}, 8 \mathrm{H})$, 
$0.962(\mathrm{t}, J=7.2 \mathrm{~Hz}, 3 \mathrm{H}), 0.980(\mathrm{t}, J=3.2 \mathrm{~Hz}, 3 \mathrm{H}) .{ }^{13} \mathrm{C}$ NMR $\left(400 \mathrm{MHz}, \mathrm{THF}-\mathrm{d}_{8}\right): \delta 164.59$, $160.18,148.89,146.15,138.03,135.62,126.01,123.60,122.60,116.86,114.16,113.00,109.00$, 98.04, 71.49, 48.36, 37.84, 31.64, 30.80, 29.83, 27.81, 14.51, 28 11.42. MS-HR-MALDI: [M] ${ }^{+}$ calculated for $\mathrm{C}_{36} \mathrm{H}_{31} \mathrm{~N}_{3} \mathrm{O}_{7}: 617.65$, found: 617.216

(2E,2'E)-3,3'-(5,5'-(10-(2-ethylhexyl)-10H-phenoxazine-3,7-diyl)bis(thiophene-5,2-diyl))bis(2cyanoacrylic acid) (DP-2). Spectroscopic data for DP-2: ${ }^{1} \mathrm{H}$ NMR $\left(400 \mathrm{MHz}, \mathrm{THF}-\mathrm{d}_{8}\right): \delta 8.31$ $(\mathrm{s}, 2 \mathrm{H}), 7.81(\mathrm{~d}, J=4.0 \mathrm{~Hz}, 2 \mathrm{H}), 7.44(\mathrm{~d}, J=4.0 \mathrm{~Hz}, 2 \mathrm{H}), 7.27(\mathrm{dd}, J=8.4,2.0 \mathrm{~Hz}, 2 \mathrm{H}), 7.08(\mathrm{~d}$, $J=2.4 \mathrm{~Hz}, 2 \mathrm{H}), 6.78(\mathrm{~d}, J=8.8 \mathrm{~Hz}, 2 \mathrm{H}), 3.63(\mathrm{~d}, J=7.6 \mathrm{~Hz}, 2 \mathrm{H}), 1.95-1.89(\mathrm{~m}, 1 \mathrm{H}), 1.56-1.29$ $(\mathrm{m}, 8 \mathrm{H}), 0.97(\mathrm{t}, J=7.6 \mathrm{~Hz}, 3 \mathrm{H}), 0.90(\mathrm{t}, J=7.2 \mathrm{~Hz}, 3 \mathrm{H}) .{ }^{13} \mathrm{C}$ NMR $\left(500 \mathrm{MHz}, \mathrm{DMSO}-\mathrm{d}_{6}\right): \delta$ $163.71,152.02,146.34,144.22,141.52,133.88,133.45,125.61,124.07,122.56,116.69,114.56$, 113.62, 112.44, 97.59, 46.71, 36.03, 29.84, 28.08, 23.37, 22.54, 13.83, 10.77. MS-HR-MALDI: $[\mathrm{M}]^{+}$calculated for $\mathrm{C}_{36} \mathrm{H}_{31} \mathrm{~N}_{3} \mathrm{O}_{5} \mathrm{~S}_{2}: 649.16$, found: 649.17

(2E,2'E)-3,3'-(5,5'-(10-(2-ethylhexyl)-10H-phenoxazine-3,7-diyl)bis(3-hexylthiophene-5,2-diyl)) bis(2-cyanoacrylic acid) (DP-3). Spectroscopic data for DP-3: ${ }^{1} \mathrm{H}$ NMR $\left(400 \mathrm{MHz}, \mathrm{THF}-\mathrm{d}_{8}\right)$ : $\delta 8.38(\mathrm{~s}, 2 \mathrm{H}), 7.35(\mathrm{~s}, 2 \mathrm{H}), 7.25(\mathrm{~d}, J=7.6 \mathrm{~Hz}, 2 \mathrm{H}), 7.06(\mathrm{~d}, J=1.6 \mathrm{~Hz}, 2 \mathrm{H}), 6.75(\mathrm{~d}, J=$ $7.6 \mathrm{~Hz}, 2 \mathrm{H}), 3.62(\mathrm{~d}, J=6.8 \mathrm{~Hz}, 2 \mathrm{H}), 2.83(\mathrm{t}, J=7.6 \mathrm{~Hz}, 4 \mathrm{H}), 1.45-1.33(\mathrm{~m}, 25 \mathrm{H}), 0.97(\mathrm{t}, J=$ $7.2 \mathrm{~Hz}, 3 \mathrm{H}), 0.90(\mathrm{t}, J=6.4 \mathrm{~Hz}, 9 \mathrm{H}) .{ }^{13} \mathrm{C}$ NMR $\left(400 \mathrm{MHz}, \mathrm{THF}-\mathrm{d}_{8}\right): \delta 164.79,156.54,152.21$, $146.18,143.84,135.47,129.89,127.52,125.93,123.36,117.04,114.07,113.79,97.85,48.36,37.99$, 32.69, 32.27, 31.82,30.03, 29.96, 29.85, 24.13, 23.59, 14.53, 14.49, 11.44. MS-HR-MALDI: [M] ${ }^{+}$ calculated for $\mathrm{C}_{48} \mathrm{H}_{55} \mathrm{~N}_{3} \mathrm{O}_{5} \mathrm{~S}_{2}$ : 817.36, found: 817.40

\section{Result and Discussion}

3.1. Synthesis

The structures of new di-anchor-based DP-1 to DP-3 organic dyes are shown in Figure 1, and the main synthetic ways are described in Scheme 1. Commercially variable $10 \mathrm{H}$-phenoxazine was firstly used for preparation of the key starting compound 10-(2ethylhexyl)phenoxazine by the similar alkylation procedure as described in literature [34]. 3,7-dibromo-10-(2-ethylhexyl)-10H-phenoxazine was obtained by bromination reaction of the 10-(2-ethylhexyl)-10H-phenoxazine according to defined procedure [35]. Suzuki coupling of 1 with aldehyde-containing boronic acid reagents provided the corresponding aldehyde precursors $\mathbf{2 a}$ and $\mathbf{2 b}$. Stille coupling of $\mathbf{1}$ with 3-hexylthiophene stannyl reagent afforded 3. Subsequent Vilsmeier-Haack reactions of 3 yielded compound 4. Finally, Knoevenagel condensation of $\mathbf{2 a}, \mathbf{2} \mathbf{b}$, and $\mathbf{4}$ with cyanoacetic acid afforded the desired dyes DP-1-DP-3.
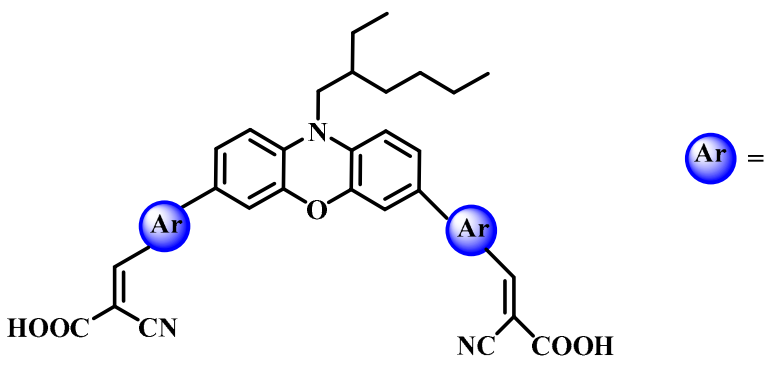

DP-1

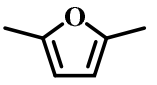

DP-2
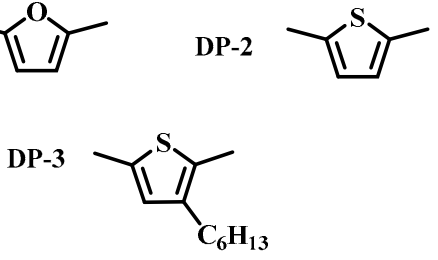

Figure 1. The structure of dyes.

\subsection{Optical Properties}

The photophysical properties of the three new dyes DP-1, DP-2, and DP-3 that were investigated by the UV-vis absorption spectra of dyes in THF are shown in Figure $2 \mathrm{a}$ and the consistent data are summarized in Table 1. As shown, DP-1, DP-2, and DP-3 exhibited similar absorption bands, having two distinct bands at around $350 \mathrm{~nm}$ and $520 \mathrm{~nm}$ in $\mathrm{THF}$, respectively. The former was assigned to the localized aromatic $\pi-\pi^{*}$ transitions, and the latter was attributed to an intramolecular charge-transfer (ICT) transition from the phenoxazine donor to the anchoring moiety. The ICT absorption maximum peaks of 
DP-1, DP-2, and DP-3 were found at 524, 526, and $528 \mathrm{~nm}$, respectively, while the emission bands were displayed at $636 \mathrm{~nm}, 653 \mathrm{~nm}$, and $647 \mathrm{~nm}$. The Stokes shifts between the absorption and the emission bands were also supported for transfer characteristics in these dyes. Figure $2 \mathrm{~b}$ shows the photoluminescence spectrum and the consistent data are summarized in Table 1. The maximum absorption peaks of DP-2 and DP-3 are slightly red-shifted compared to that of DP-1 with furan linker. It indicated that the delocalization of electrons over whole molecules with different $\pi$-spacers decreased in the order of $\mathrm{n}$ hexylthiophene $>$ thiophene $>$ furan. In addition, the molar extinction coefficients $(\varepsilon)$ of these ICT bands significantly increased in the order of DP-1 $\left(1.5 \times 10^{4} \mathrm{M}^{-1} \mathrm{~cm}^{-1}\right)>$ DP-2 $\left(4.2 \times 10^{4} \mathrm{M}^{-1} \mathrm{~cm}^{-1}\right)>$ DP-3 $\left(4.8 \times 10^{4} \mathrm{M}^{-1} \mathrm{~cm}^{-1}\right)$. The organic dyes have higher molar extinction coefficients that were beneficial for device fabrication afforded to use thinner $\mathrm{TiO}_{2}$ film. Amongst these dyes, DP-3 exhibits the broadest and the most intense absorption spectra.

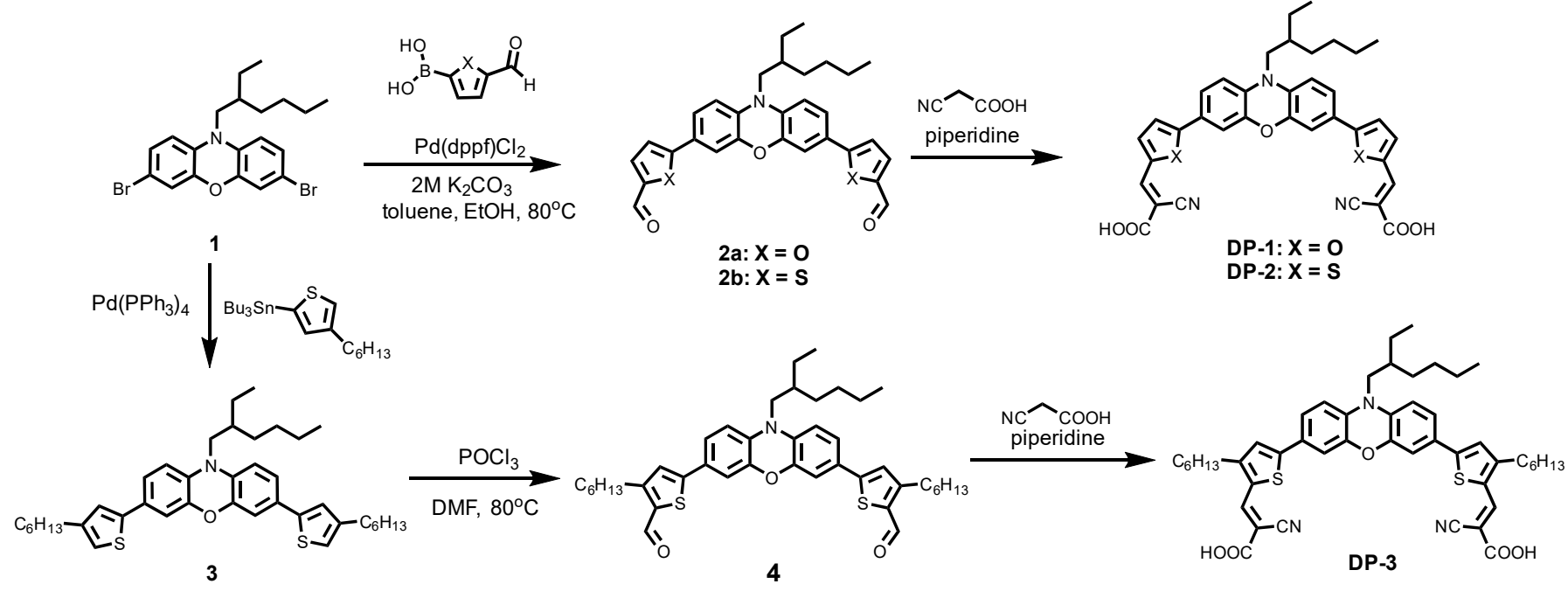

Scheme 1. Synthetic pathways of the DP dyes.
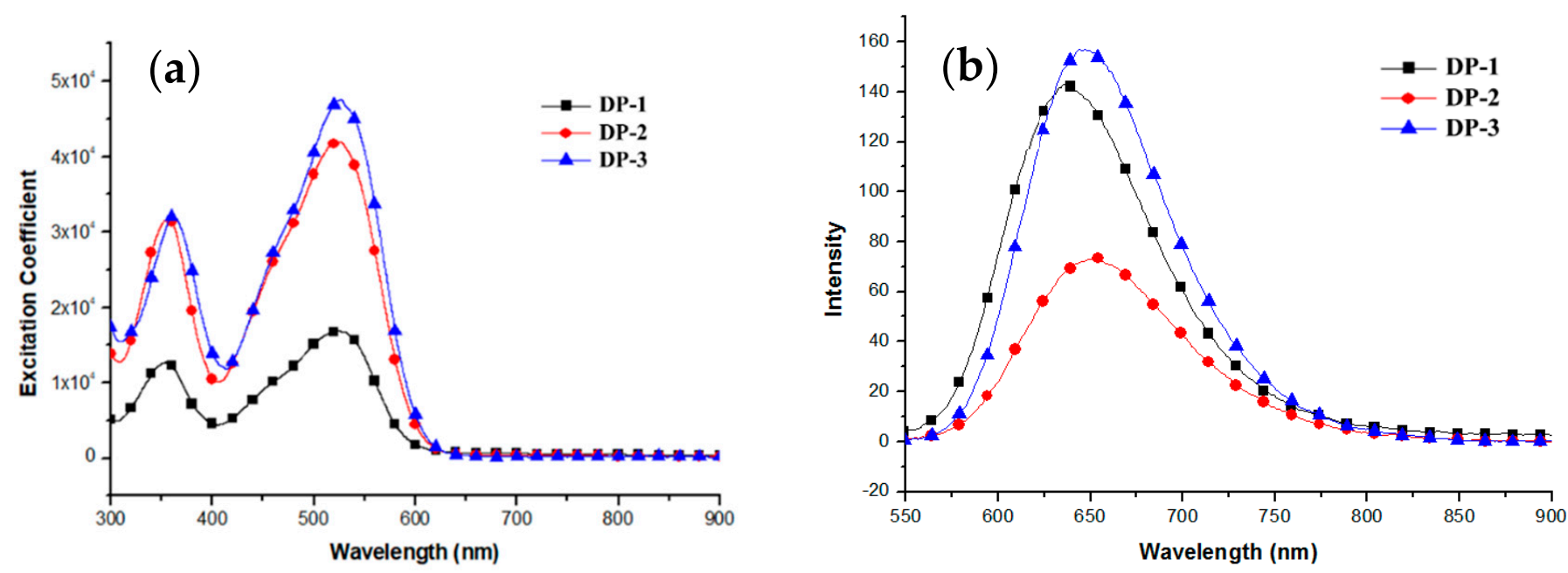

Figure 2. (a) Absorption spectra of dyes in THF solutions; (b) the emission spectra of the dyes in THF. 
Table 1. Electrooptical and electrochemical parameters of the dyes.

\begin{tabular}{|c|c|c|c|c|c|c|}
\hline Dye & $\begin{array}{c}\lambda_{\text {abs }}, \mathbf{n m} \\
\left(\varepsilon, M^{-1} \mathbf{c m}^{-1}\right)^{a}\end{array}$ & $\begin{array}{l}\lambda_{\mathrm{em}} \\
\mathrm{nm}^{\mathrm{a}}\end{array}$ & $\begin{array}{c}E_{o x} b \\
(V \text { vs. } N H E)\end{array}$ & $\begin{array}{c}\mathrm{E}_{0-0} \\
\mathrm{eV}\end{array}$ & $\begin{array}{c}E_{0-0} * d \\
(V \text { vs. } \text { NHE })\end{array}$ & HOMO/LUMO(eV) \\
\hline DP-1 & $524(16,862)$ & 636 & 1.02 & 2.12 & -1.10 & $5.42 / 3.30$ \\
\hline DP-2 & $526(41,950)$ & 653 & 1.01 & 2.10 & -1.09 & $5.41 / 3.31$ \\
\hline DP-3 & $528(47,760)$ & 647 & 1.00 & 2.09 & -1.09 & $5.40 / 3.31$ \\
\hline
\end{tabular}

${ }^{a}$ Recorded in THF solutions at $298 \mathrm{~K} \cdot{ }^{b} \mathrm{E}_{\mathrm{ox}}$. The ground state oxidation potential vs. NHE. ${ }^{\mathrm{c}}$ The bandgap, $\mathrm{E}_{0-0}$, was determinated from the absorption onset. ${ }^{\mathrm{d}} \mathrm{E}_{0-0} *$ : The excited state oxidation potential vs. NHE.

The absorption spectra of the three dyes (DP-1, DP-2, and DP-3) adsorbed onto $\mathrm{TiO}_{2}$ films with and without CDCA are shown in Figure 3. Generally, the absorption maxima of organic dyes on $\mathrm{TiO}_{2}$ films would change due to the effect of the deprotonation in the adsorption process and the aggregation state of dyes on $\mathrm{TiO}_{2}$ films. When DP-1, DP-2, and DP-3 adsorbed on the $\mathrm{TiO}_{2}$ surface, the absorption spectra of the three dyes were broadened and absorption bands at the long-wavelength side are blue-shift compared to that of the solution spectra, which could be ascribed to the H-type aggregation or the deprotonation of the carboxylic acid upon being adsorbed on $\mathrm{TiO}_{2}$ [36,37]. In addition, it was distinguished that the absorption spectra of the three dyes anchored onto the $\mathrm{TiO}_{2}$ film exposed a slightly broad outline compared to those in solution, which was helpful for light-harvesting. CDCA was added to check the dye aggregation with DP dyes on $\mathrm{TiO}_{2}$ film, as displayed in Figure 3.

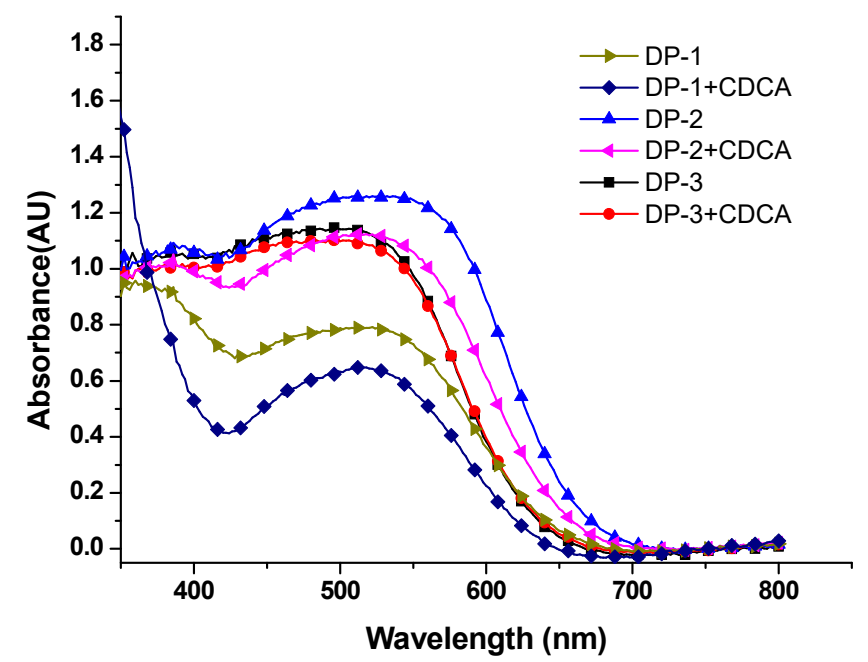

Figure 3. The absorption spectra of DP-1, DP-2, and DP-3 on $\mathrm{TiO}_{2}$ films.

After the addition of CDCA, there was no obvious change for $\lambda_{\max }$ of the three dyes, but the absorption intensity showed a decrease for DP-1 and DP-2, which may be due to increased surface coverage of $\mathrm{TiO}_{2}$ with CDCA. In contrast, DP-3, with hexyl-thiophene linker, displayed a slightly decreased absorption intensity when $10 \mathrm{mM} \mathrm{CDCA}$ was added, indicating that the hexyl substituent of the thiophene entity helps with suppression of dye aggregation.

\subsection{Electrochemical Properties}

The energetic arrangement of the highest occupied molecular orbital (HOMO) and lowest unoccupied molecular orbital (LUMO) energy levels is fundamental for an efficient operation of the organic sensitizer in DSSCs. The electrochemical properties of DP-1 to DP-3 were analyzed by cyclic voltammetry in THF solution. The representative cyclic voltammograms of the dyes are shown in Figure 4 and the relevant electrochemical data are presented in Table 1. All redox potentials are referenced to ferrocene utilized as an internal standard for calibrating the potential and calculating the HOMO levels. The excited state 
potential $\left(\mathrm{E}_{0-0^{*}}\right)$ of the sensitizer was estimated from the first oxidation potential $\left(\mathrm{E}_{\mathrm{ox}}\right)$ at the ground state and the zero-zero excitation energy $\left(\mathrm{E}_{0-0}\right)$ estimated from the absorption onset. The assumed $E_{0-0^{*}}$ values $(-1.10$ to $-1.09 \mathrm{~V}$ vs. NHE, see Table 1$)$ are more negative than the conduction band edge energy level of the $\mathrm{TiO}_{2}$ electrode (-0.5 V vs. NHE) [38], and the first oxidation potentials of the dyes DP-1, DP-2, DP-3 were measured to be 1.02, 1.01 , and $1.00 \mathrm{~V}$ vs. NHE are more positive than the $\mathrm{I}^{-} / \mathrm{I}_{3}{ }^{-}$redox couple $(\sim 0.4 \mathrm{~V}$ vs. NHE) [39]. These results ensure favorable electron injection upon photoexcitation and regeneration of the dye after electron injection.

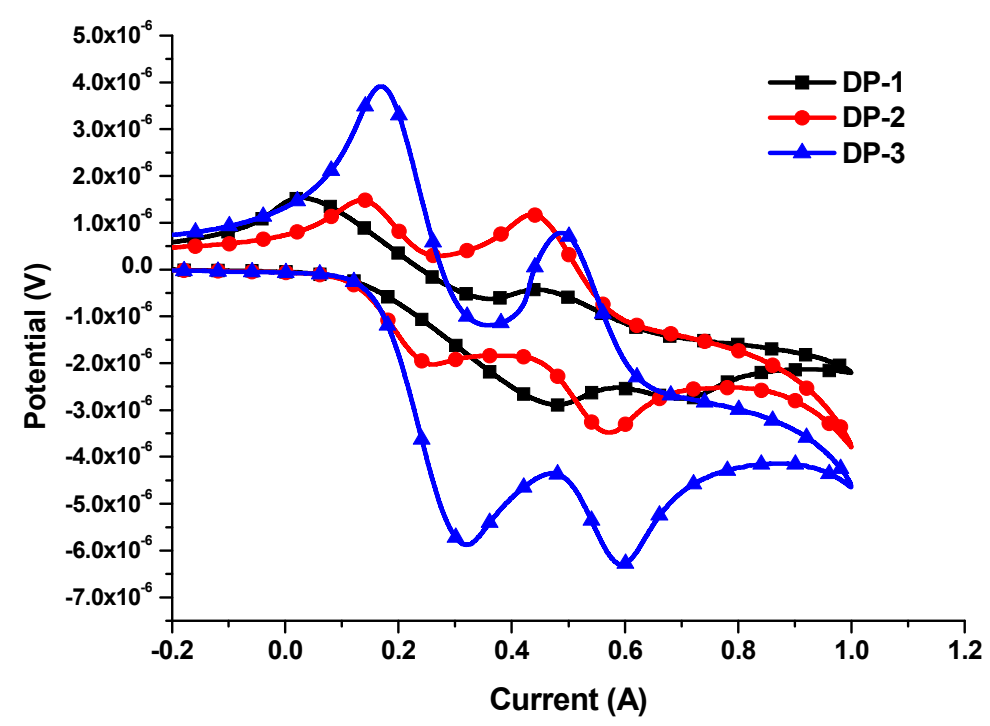

Figure 4. Cyclic voltammograms of DP-1 to DP-3.

\subsection{Photovoltaic Properties}

The DSSCs of DP dyes were fabricated using these three dyes as photosensitizers and measured under AM $1.5 \mathrm{G}$ irradiation $\left(100 \mathrm{~mW} \mathrm{~cm}^{-2}\right)$. The current density-voltage $(J-V)$ curves under illumination and in the dark are shown in Figure 5. The photovoltaic performance statistics under a solar condition (AM 1.5) illumination are collected in Table 2. All the devices exhibited power conversion efficiencies ranging from 1.53 to $3.96 \%$. Under the same condition, the power conversion efficiency of reference dye N719-based cell showed 7.38\%. DSSCs based on DP-1 and DP-3 dyes exhibited overall power conversion efficiencies of $1.53 \%$ and $2.92 \%$, with $J_{\mathrm{SC}}$ of $3.31 \mathrm{~mA} \mathrm{~cm}^{-2}$ and $J_{\mathrm{SC}}=5.62 \mathrm{~mA} \mathrm{~cm}^{-2}, V_{\mathrm{OC}}$ of $0.64 \mathrm{~V}$ and $V_{\mathrm{OC}}$ of $0.68 \mathrm{~V}$, and FF of 0.72 and FF of 0.76 , respectively. In comparison, the device based on DP-2 gave a short-circuit photocurrent density $\left(J_{\mathrm{SC}}\right)$ of $8.14 \mathrm{~mA} \mathrm{~cm}^{-2}$, an open-circuit voltage $\left(V_{\mathrm{OC}}\right)$ of $0.68 \mathrm{~V}$, and a fill factor $(\mathrm{FF})$ of 0.69 , consistent with an overall conversion efficiency $(\eta)$ of $3.80 \%$. The $V_{\text {OC }}$ value of DP-2 and DP-3 was $40 \mathrm{mV}$ higher than that of DP-1, which could be attributed to the smaller dark current for DP-2 and DP-3. In other words, DP-1 with furan moiety had the lowest Jsc value and poor photovoltaic performance. The device efficiencies are in the order of DP-2 > DP-3 > DP-1 and the performances of the devices based on DP-2 are $~ 51 \%$ of the standard cell based on ruthenium dye N719. The adsorbed dye densities of the sensitizers on $\mathrm{TiO}_{2}$ were measured to be $3.70 \times 10^{-7}, 4.2 \times 10^{-7}$, and $2.1 \times 10^{-7} \mathrm{~mol} / \mathrm{cm}^{2}$ for DP-1, DP-2, and DP-3, respectively. The low dye density on $\mathrm{TiO}_{2}$ of DP-3 might be attributed to more steric congestion of $n$-hexylthiophene linker owing to the presence of an extra n-hexyl chain. The higher cell efficiency of DP-2 than DP-3 and DP-1 is ascribed to the better light-harvesting of DP-2 and its slightly higher dye density amount on $\mathrm{TiO}_{2}$ film compared to the other two dyes. DP-2 has better light-harvesting efficiency in the film among the three DP dyes; it also has greatly higher incident monochromatic photo-to-current conversion efficiency (IPCE) values than the other two dyes in the range of $400-700 \mathrm{~nm}$. The result indicates that 
DP-2 has the highest photocurrent due to higher dye absorption density on $\mathrm{TiO}_{2}$ and faster and more effective electron injection efficiency.

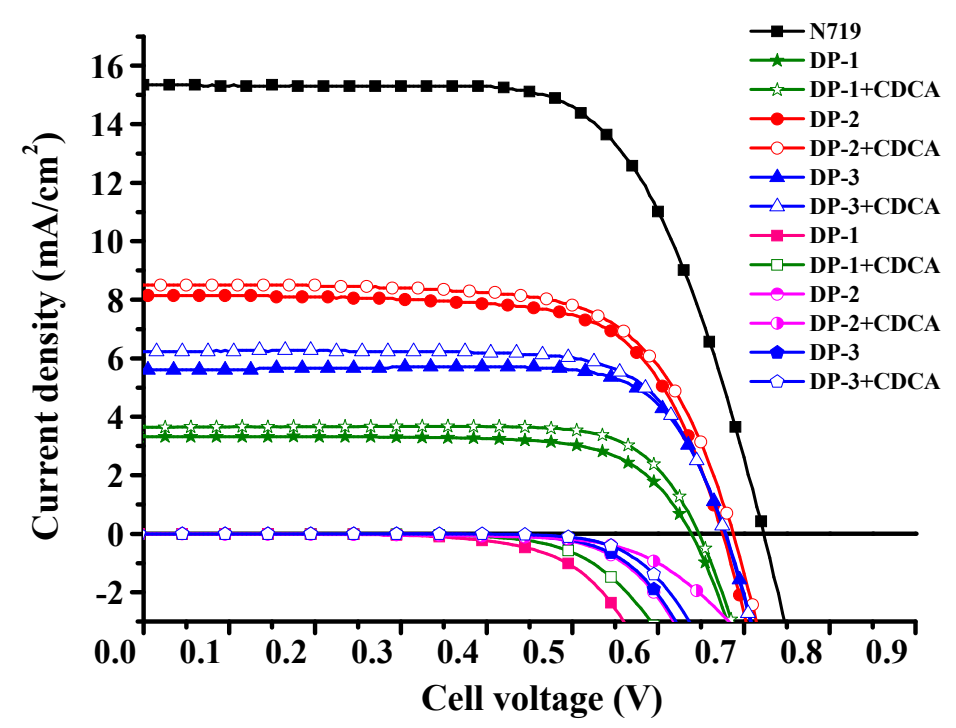

Figure 5. $J-V$ curves and dark currents of dye-sensitized solar cells (DSSCs) based on the dyes.

Table 2. Performance parameters of DSSCs constructed using the dyes.

\begin{tabular}{ccccc}
\hline Dye & $V_{\text {OC }}(\mathrm{V})$ & $J_{\text {SC }}\left(\mathbf{m A} / \mathbf{c m}^{\mathbf{2}}\right)$ & $\boldsymbol{\eta} \mathbf{( \% )}$ & FF \\
\hline DP-1 & 0.64 & 3.31 & 1.53 & 0.72 \\
DP-2 & 0.68 & 8.14 & 3.80 & 0.69 \\
DP-3 & 0.68 & 5.62 & 2.92 & 0.76 \\
DP-1 +10 mMCDCA & 0.65 & 3.64 & 1.80 & 0.76 \\
DP-2 +10 mMCDCA & 0.69 & 8.52 & 3.96 & 0.67 \\
DP-3 + 10 mMCDCA & 0.68 & 6.23 & 3.10 & 0.74 \\
N719 & 0.72 & 15.36 & 7.38 & 0.67 \\
\hline
\end{tabular}

The incident monochromatic photo-to-current conversion efficiency (IPCE) plots of the cells are shown in Figure 6, respectively. Well-consistent with adsorption spectra in $\mathrm{TiO}_{2}$, DP-2 exhibited broader and higher IPCE efficiencies. The IPCE value for DP-2 at around $520 \mathrm{~nm}(60 \%)$ is higher than that of DP-1 (39\%) or DP-3 (17\%). IPCE is related to the light-harvesting efficiency of the photoelectrode and electron injections yield and charge collection efficiency. The higher IPCE values of the DSSC devices based on DP-2 or DP-3 with thiophene or hexylthiophene linkers have higher electron transfer yield than the dye with furan linker. This indicated that the introduction of thiophene heteroaromatic ring into phenoxazine-based sensitizer structure has a positive effect.

Suppression of dye aggregation was also supported by the blue shift of the absorption spectra of the DP dyes on the $\mathrm{TiO}_{2}$ film when CDCA was added. The cell performance data with CDCA co-adsorbent are summarized in Table 2. The three dyes have slight improvements in the cell performance upon addition of CDCA: PCE $=1.80 \%, J_{\mathrm{SC}}=3.64 \mathrm{mAcm}^{-2}$, $V_{\mathrm{OC}}=0.65 \mathrm{~V}, \mathrm{FF}=0.76$ for DP-1; PCE $=3.96 \%, J_{\mathrm{SC}}=8.52 \mathrm{mAcm}^{-2}, V_{\mathrm{OC}}=0.69 \mathrm{~V}, \mathrm{FF}=0.67$ for DP-2; PCE $=3.10 \%, J_{\mathrm{SC}}=6.23 \mathrm{mAcm}^{-2}, V_{\mathrm{OC}}=0.68 \mathrm{~V}, \mathrm{FF}=0.74$ for DP-3. For DP-1 to DP- 3, the cell performance improved only marginally upon addition of CDCA $10 \mathrm{mM}$, $V_{\mathrm{OC}}$ stayed almost the same, whereas $J_{\mathrm{SC}}$ continued to increase. Hence, anti-aggregation of the dyes was alleviated by CDCA adsorption. By adding $10 \mathrm{mM} \mathrm{CDCA}$, devices with DP-2 showed the better $J_{\mathrm{SC}}, V_{\mathrm{OC}}$, and conversion efficiency of $3.96 \%$ (Table 2). 


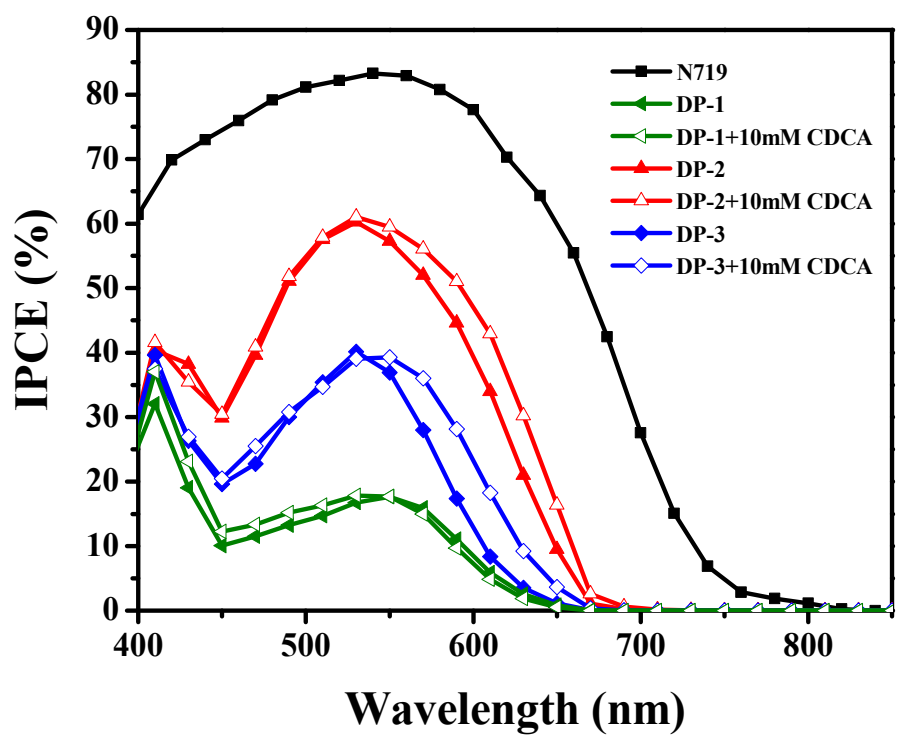

Figure 6. Incident monochromatic photo-to-current conversion efficiency (IPCE) plots of the DSSCs using the dyes and N719.

\subsection{Electrochemical Impedance Spectroscopy Analysis}

The electrochemical impedance spectroscopy (EIS) is a very useful technique to understand the electron injection and recombination processes in DSSCs [40]. Electrochemical impedance spectroscopy (EIS) was used to further evaluate the important interfacial charge transfer processes in a DSSC. Generally, there are three semicircles showed in the EIS spectrum, which correspond to electron recombination resistances (Rrec) at the interfaces of photoanode/dye/electrolyte, charge-transfer resistance at the photoanode/dye/electrolyte interface (RCT), and Warburg diffusion process of electrolyte (Zw), as typically reported for other DSSC devices [41-43]. The electrochemical impedance spectra (EIS) of DSSCs were obtained under a forward bias of $-0.70 \mathrm{~V}$ in the dark to elucidate correlation of $V_{\mathrm{OC}}$ with those dyes, and the Nyquist plots for DSSCs based on DP-1 to DP-3 are shown in Figure 7. The large semicircle in the Nyquist plots is attributed to the charge recombination resistance between the $\mathrm{TiO}_{2}$ and the electrolyte $\left(\mathrm{R}_{\text {rec }}\right)$, where the larger $\mathrm{R}_{\text {rec }}$ value suggests the smaller dark current. The radius of the biggest semicircle increases in the order of DP-1 $<$ DP-3 $<$ DP-2. The cell of DP-2 and DP-3 exhibits a much larger resistance value than that of DP-1, which is consistent with its smaller dark current and larger $V_{\mathrm{OC}}$ measured.

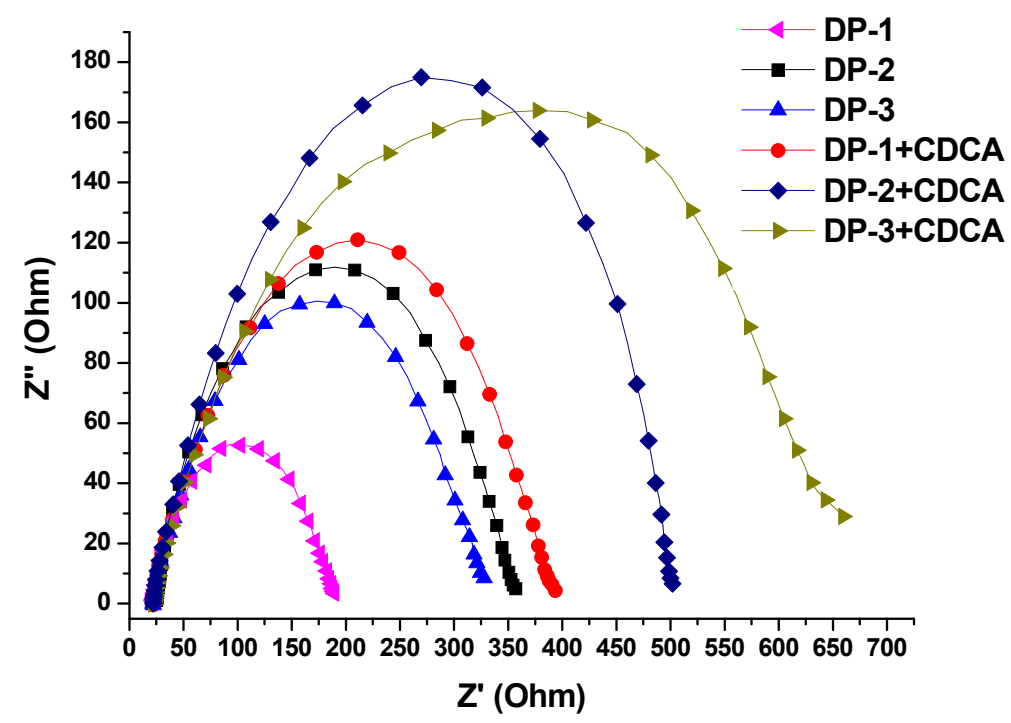

Figure 7. Nyquist plots of DSSCs based on dyes measured at $-0.7 \mathrm{~V}$ forward bias in the dark. 


\subsection{Computational Calculation}

In order to gain insight into the relationship between the geometrical and electronic properties of the DP dyes, the dyes DP-1 to DP-3 were further investigated through theoretical calculations. The results for theoretical computation are included in Table 3. Figure 8 shows the ground-state geometries of the dyes with the dihedral angles between the two neighboring conjugated segments indicated. In the optimized structure, DP-1 has a nearly planar structure where the torsion angle between phenoxazine and the furan entity is almost $0^{\circ}$. The planarity structure of DP-1 can increase the stacking of the dye molecules, inducing more dye aggregation. In comparison, the dihedral angle between the phenoxazine and the thiophene entity is larger than $20^{\circ}$ for DP-2 and DP-3. The smaller planarity of DP-2 and DP-3 leads to better charge separation between the phenoxazine unit and accepter unit. The electron distributions of the HOMOs and LUMOs for DP-1, DP-2, and DP-3 are illustrated in Figure 9. The HOMOs of DP-1, DP-2, and DP-3 are delocalized on the entire molecule including acceptor, whereas the LUMO and LUMO+1 of these molecules are mainly distributed from the $\pi$-spacer acceptor to the acceptor. In Table 3 , the $\mathrm{S}_{0} \rightarrow \mathrm{S}_{1}$ transition is nearly a $\mathrm{HOMO} \rightarrow$ LUMO transition. Therefore, the lowest energy absorption has charge transfer character for these dyes. The more intense electronic absorptions in DP-2 and DP-3 than DP-1 are supported by its larger computed oscillation strength (f). The Mulliken charges variation for the $S_{1}$ and $S_{2}$ states were calculated from the TD-DFT results. Differences in the Mulliken charges in the excited and the ground states were calculated and gathered into several segments, heteroaromatic ring $\left(\mathrm{F}, \mathrm{T}, \mathrm{T}_{1}\right)$, phenoxazine $(\mathrm{Poz})$, heteroaromatic ring $\left(\mathrm{F}^{\prime}, \mathrm{T}^{\prime}, \mathrm{T}_{1^{\prime}}\right)$, and 2-cyanoacrylic acid (Ac), 2-cyanoacrylic acid (Ac') to estimate the extent of charge separation upon excitation. Figure 10 displays the changes in Mulliken charges of the dyes for the $S_{0} \rightarrow S_{1}$ and $S_{0} \rightarrow$ $S_{2}$ transitions. In DP-1 to DP-3, the positive charges exist at phenoxazine in the dyes for $S_{0} \rightarrow S_{1}$ and $S_{0} \rightarrow S_{2}$ transitions. On the other hand, DP-1 to DP-3 have prominent negative charges at both acceptors for both $S_{0} \rightarrow S_{1}$ and $S_{0} \rightarrow S_{2}$ transitions, indicating that both acceptors can function as the electron injection channels.<smiles></smiles>

DP-1

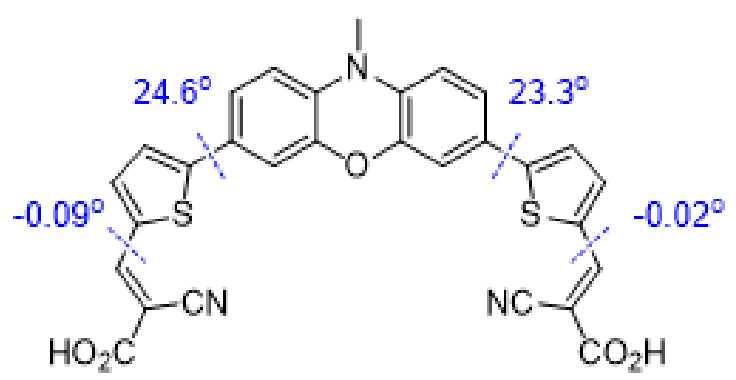

DP-2<smiles>[R66]c1cc(-c2ccc3c(c2)Oc2cc(-c4cc(C)c(/C=C(/C)C(=O)O)s4)ccc2N3C)sc1/C=C(/C#N)C(=O)O</smiles>

\section{DP-3}

Figure 8. Schematic division and dihedral angles of molecules. 
Table 3. Calculated lower-lying transitions of the dyes ${ }^{\text {a }}$.

\begin{tabular}{|c|c|c|c|c|c|c|c|c|c|c|c|c|c|}
\hline Dye & State & Excitation $^{b}$ & $\lambda_{\text {cal },}, \mathrm{eV}$ & $f^{\mathrm{c}}$ & $\begin{array}{c}\Delta(\text { Mulliken } \\
\text { charge), d | e | }\end{array}$ & $f \times \Delta \mathbf{q}$ & Dye & State & Excitation $^{b}$ & $\lambda_{\mathrm{cal},}, \mathrm{eV}$ & $f^{\mathrm{c}}$ & $\begin{array}{c}\Delta(\text { Mulliken } \\
\text { charge), d | e | }\end{array}$ & $f \times \Delta \mathbf{q}$ \\
\hline \multirow{3}{*}{ GF1 } & $\mathrm{S}_{1}$ & $\mathrm{H} \rightarrow \mathrm{L}(99 \%)$ & 2.19 & 0.34 & 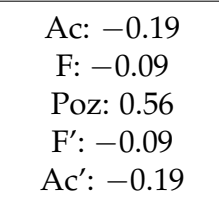 & -0.13 & GF2 & $\mathrm{S}_{1}$ & $\mathrm{H} \rightarrow \mathrm{L}(99 \%)$ & 2.21 & 0.57 & $\begin{array}{c}\text { Ac: }-0.19 \\
\text { T: }-0.14 \\
\text { Poz: } 0.61 \\
T^{\prime}:-0.12 \\
\text { Ac': }-0.17\end{array}$ & -0.20 \\
\hline & $\mathrm{S}_{2}$ & $\begin{array}{c}\mathrm{H} \rightarrow \mathrm{L} 1 \\
(95 \%)\end{array}$ & 2.47 & 0.20 & $\begin{array}{c}\text { Ac: }-0.23 \\
\text { F: }-0.09 \\
\text { Poz: } 0.64 \\
\text { F': }^{\prime}-0.09 \\
\text { Ac': }-0.23\end{array}$ & -0.09 & & $\mathrm{~S}_{2}$ & $\begin{array}{c}\mathrm{H} \rightarrow \mathrm{L} 1 \\
(97 \%)\end{array}$ & 2.47 & 0.20 & 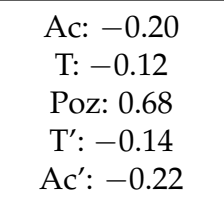 & -0.08 \\
\hline & $\mathrm{S}_{3}$ & $\begin{array}{c}\mathrm{H} 2 \rightarrow \mathrm{L} 1 \\
(6 \%) \mathrm{H} 1 \rightarrow \mathrm{L} \\
(91 \%)\end{array}$ & 3.23 & 0.62 & $\begin{array}{c}\text { Ac: }-0.12 \\
\text { F: } 0.05 \\
\text { Poz: } 0.14 \\
\text { F': }^{\prime} 0.05 \\
\text { Ac': }-0.12\end{array}$ & -0.15 & & $\mathrm{~S}_{3}$ & $\begin{array}{c}\mathrm{H} 1 \rightarrow \mathrm{L} \\
(95 \%)\end{array}$ & 3.27 & 0.54 & $\begin{array}{c}\text { Ac: }-0.11 \\
\text { T: } 0.01 \\
\text { Poz: } 0.11 \\
T^{\prime}: 0.05 \\
\text { Ac': }-0.06\end{array}$ & -0.09 \\
\hline \multirow{3}{*}{ GF3 } & $\mathrm{S}_{1}$ & $\mathrm{H} \rightarrow \mathrm{L}(99 \%)$ & 2.20 & 0.58 & $\begin{array}{l}\text { Ac: }-0.18 \\
\text { T1: }-0.14 \\
\text { Poz: } 0.59 \\
\text { T1': }-0.12 \\
\text { Ac': }-0.16^{\prime}\end{array}$ & -0.20 & & & & & & & \\
\hline & $\mathrm{S}_{2}$ & $\begin{array}{c}\mathrm{H} \rightarrow \mathrm{L} 1 \\
(96 \%)\end{array}$ & 2.46 & 0.19 & $\begin{array}{c}\text { Ac: }-0.19 \\
\text { T1: }-0.12 \\
\text { Poz: } 0.66 \\
\text { T1': }-0.14 \\
\text { Ac': }-0.21\end{array}$ & -0.07 & & & & & & & \\
\hline & $\mathrm{S}_{3}$ & $\begin{array}{l}\mathrm{H} 1 \rightarrow \mathrm{L} \\
\quad(94 \%)\end{array}$ & 3.19 & 0.56 & $\begin{array}{c}\text { Ac: }-0.10 \\
\text { T1: } 0.01 \\
\text { Poz: } 0.09 \\
\text { T1': } 0.05 \\
\text { Ac': }^{\prime}-0.05\end{array}$ & -0.08 & & & & & & & \\
\hline
\end{tabular}

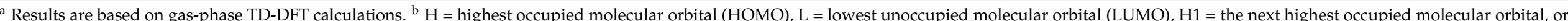

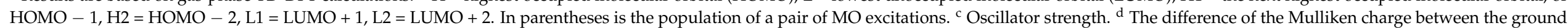
state and excited state. 


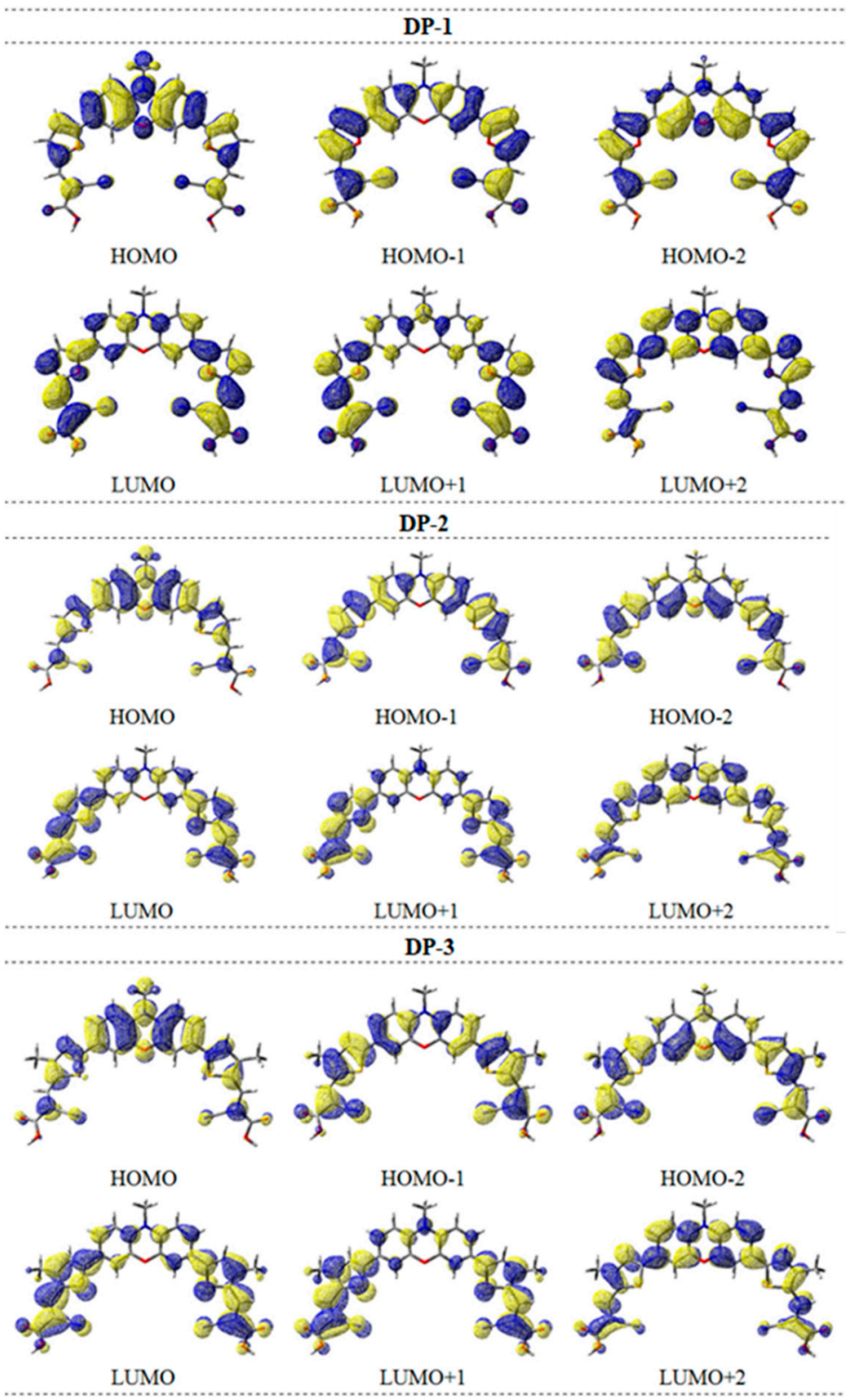

Figure 9. Selected frontier orbitals of the dyes.

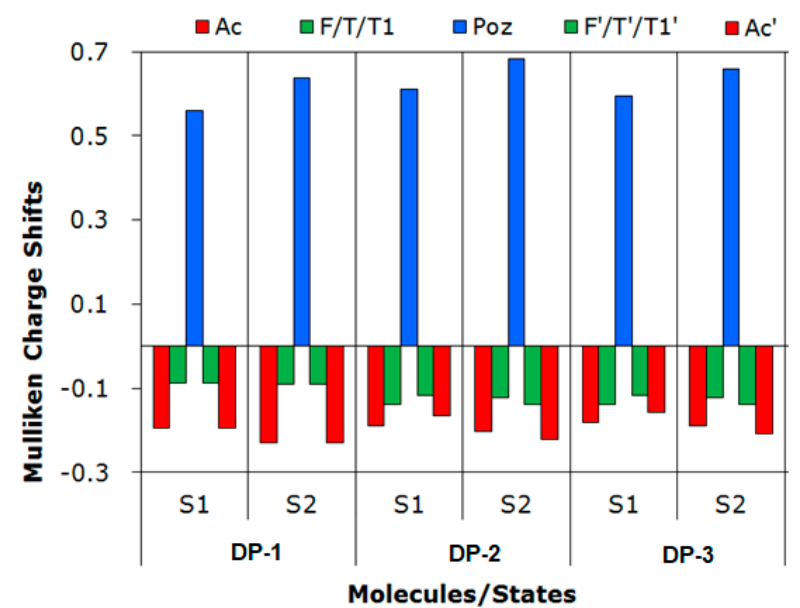

Figure 10. Plot of the difference in the Mulliken charges between the ground state and the excited state. 


\section{Conclusions}

In summary, we reported the new phenoxazine-based organic dyes containing a 2ethylhexyl substituent at the nitrogen atom of the phenoxazine and two 2-cyanoacrylic acids as the acceptors in addition to anchors. The influences of the various $\pi$ bridges on the photophysical, electrochemical, and photovoltaic properties of these sensitizers were investigated. The results of calculation and experiments clearly demonstrate that photophysical properties can be regulated by introducing different $\pi$-conjugated bridges. Then, the performance of the DSSCs based on these dyes were tested and analyzed, and, among which, the DP-2 cell shows the best PCE of 3.80\% without CDCA among all. DSSCs using these three DP dyes as the sensitizers showed efficiencies ranging from 1.53 to $3.80 \%$ without CDCA under simulated AM1.5G irradiation. Upon addition of CDCA as a co-adsorbent, the cell efficiency has been further improved to $3.96 \%$ for DSSCs based on DP-2, which is about $54 \%$ of the N719-based standard cell. Our future work will focus on optimization of molecular structure to fine-tune the energy levels of the dye toward higher $V_{\mathrm{OC}}, J_{\mathrm{SC}}$, and panchromatic DSSCs.

Author Contributions: Conceptualization, Y.-S.Y.; software, Y.-S.Y.; formal analysis, V.I.; investigation, V.I.; resources, Y.-S.Y.; data curation, V.I.; writing-original draft preparation, V.I.; writingreview and editing, Y.-S.Y.; supervision, Y.-S.Y.; project administration, Y.-S.Y.; funding acquisition, Y.-S.Y. Both authors have read and agreed to the published version of the manuscript.

Funding: This research was funded by Ministry of Science and Technology, Taiwan. Grant number is MOST 107-2113-M-033-009-MY2.

Institutional Review Board Statement: Not applicable.

Informed Consent Statement: Not applicable.

Data Availability Statement: The data presented in this study are available on request from the corresponding author.

Conflicts of Interest: The authors declare no conflict of interest.

\section{References}

1. Reagen, B.O.; Gratzel, M. High-Efficiency Solar Cell Based on Dye-Sensitized Colloidal TiO 2 Films. Nature 1991, 353, 737-740. [CrossRef]

2. Anscombe, N. Solar cells that mimic plants. Nat. Photonics 2011, 5, 266-267. [CrossRef]

3. Mathew, S.; Yella, A.; Gao, P.; Humphry-Baker, R.; Curchod, B.F.E.; Ashari-Astani, N.; Tavernelli, I.; Rothlisberger, U.; Nazeeruddin, M.K.; Grätzel, M. Dye-Sensitized Solar Cells with 13\% Efficiency Achieved through the Molecular Engineering of Porphyrin Sensitizers. Nat. Chem. 2014, 6, 242-247. [CrossRef] [PubMed]

4. Decoppet, J.D.; Tsai, J.H.; Grätzel, C.; Wu, C.G.; Zakeeruddin, S.M.; Grätzel, M. Highly Efficient Light-Harvesting Ruthenium Sensitizer for Thin-Film Dye-Sensitized Solar Cells. ACS Nano 2009, 3, 3103-3109.

5. Yao, Z.; Zhang, M.; Wu, H.; Yang, L.; Li, R.; Wang, P. Donor/acceptor indenoperylene dye for highly efficient organic dyesensitized solar cells. J. Am. Chem. Soc. 2015, 137, 3799-3802. [CrossRef]

6. Hung, W.I.; Liao, Y.Y.; Lee, T.H.; Ting, Y.C.; Ni, J.S.; Kao, W.S.; Lin, J.T.; Wei, T.C.; Yen, Y.S. Eugenic metal-free sensitizers with double anchors for high performance dye-sensitized solar cells. Chem. Commun. 2015, 51, 2152-2155. [CrossRef]

7. Yen, Y.S.; Chou, H.H.; Chen, Y.C.; Hsu, C.Y.; Lin, J.T. Recent Developments in Molecule-Based Organic Materials for Dye-Sensitized Solar Cells. J. Mater. Chem. 2012, 22, 8734-8747. [CrossRef]

8. Lee, C.P.; Li, C.T.; Ho, K.C. Use of organic materials in dye-sensitized solar cells. Mater. Today 2017, 20, 267-283. [CrossRef]

9. Pashaei, B.; Shahroosvand, H.; Graetzel, M.; Nazeeruddin, M.K. Influence of Ancillary Ligands in Dye-Sensitized Solar Cells. Chem. Rev. 2016, 116, 9485-9564. [CrossRef]

10. Mahmood, A. Triphenylamine based dyes for dye sensitized solar cells: A review. Sol. Energy 2016, 123, 127-144. [CrossRef]

11. Ji, J.; Zhou, H.; Kim, H. Rational design criteria for D- $\pi$-A structured organic and porphyrin sensitizers for highly efficient dye-sensitized solar cells. J. Mater. Chem. A 2018, 6, 14518-14545. [CrossRef]

12. Liang, M.; Liu, Y.; Xiao, B.; Yang, S.; Wang, Z.; Han, H. An analytical model for the transverse permeability of gas diffusion layer with electrical double layer effects in proton exchange membrane fuel cells. Int. J. Hydrog. Energy 2018, 43, 17880-17888. [CrossRef]

13. Liang, M.; Fu, C.; Xiao, B.; Luo, L.; Wang, Z. A fractal study for the effective electrolyte diffusion through charged porous media. Int. J. Heat Mass Transf. 2019, 137, 365-371. [CrossRef] 
14. Mao, J.; Guo, F.; Ying, W.; Wu, W.; Li, J.; Hua, J. Benzotriazole-Bridged Sensitizers Containing a Furan Moiety for Dye-Sensitized Solar Cells with High Open-Circuit Voltage Performance. Chem. Asian J. 2012, 7, 982-991. [CrossRef]

15. Chen, W.C.; Nachimuthu, S.; Jiang, J.C. Revealing the influence of Cyano in Anchoring groups of Organic Dyes on Adsorption Stability and Photovoltaic Properties for Dye-Sensitized Solar Cells. Sci. Rep. 2017, 10, 4979. [CrossRef]

16. Zhang, L.; Cole, J.M. Anchoring Groups for Dye-Sensitized Solar Cells. ACS Appl. Mater. Interfaces 2015, 7, 3427-3455. [CrossRef] [PubMed]

17. Yen, Y.S.; Ni, J.S.; Lin, T.Y.; Hung, W.I.; Lin, J.T.; Yeh, M.C.P. Imidazole-based sensitizers containging double anchors for dye-sensitized solar cells. Eur. J. Org. Chem. 2015, 2015, 7367-7377. [CrossRef]

18. Kumar, D.; Chen, Y.L.; Tsai, C.H.; Wong, K.T. Dihydophenazine-based double-anchoring dye for dye-sensitized solar cells. J. Chin. Chem. Soc. 2020, 67, 361-369. [CrossRef]

19. Zhang, W.; Dai, X.; Liao, X.; Zang, X.; Zhang, H.; Yin, X.; Yu, C.; Ke, C.; Hong, Y. Phenothiazine (or phenoxazine) based (D- $\pi-A)-$ $\mathrm{L}_{2}-(\mathrm{A}-\pi-\mathrm{D}-\pi-\mathrm{A})_{2}$-type organic dyes with five anchors for efficient dye-sensitized solar cells. Sol. Energy 2020, 212, $220-230$. [CrossRef]

20. Ren, X.; Jiang, S.; Cha, M.; Zhou, G.; Wang, Z.S. Thiophene-bridged double D- $\pi$-A dye for efficient dye-sensitized solar cell. Chem. Mater. 2012, 24, 3493-3499. [CrossRef]

21. Hung, W.I.; Liao, Y.Y.; Hsu, C.Y.; Chou, H.H.; Lee, T.H.; Kao, W.S.; Lin, J.T. High-performance dye-sensitized solar cells based on phenothiazine dyes containing double anchors and thiophene spacers. Chem. Asian J. 2014, 9, 357-366. [CrossRef]

22. Lin, R.Y.Y.; Wu, F.L.; Chang, C.H.; Chou, H.H.; Chuang, T.M.; Chu, T.C.; Hsu, C.Y.; Chen, P.W.; Ho, K.C.; Lo, Y.H.; et al. Y-shaped metal-free $\mathrm{D}-\pi-(\mathrm{A})_{2}$ sensitizers for high-performance dye-sensitized solar cells. J. Mater. Chem. 2014, 2, 3092-3101.

23. Jiang, X.; Karlsson, K.M.; Gabrielsson, E.; Johansson, E.M.; Quintana, M.; Karlsson, M.; Sun, L.; Boschloo, G.; Hagfeldt, A. Highly efficient solid-state dye-sensitized solar cells based on triphenylamine dyes. Adv. Funct. Mater. 2011, 21, 2944-2952. [CrossRef]

24. Shang, H.; Luo, Y.; Guo, X.; Huang, X.; Zhan, X.; Jiang, K.; Meng, Q. The effect of anchoring group number on the performance of dye-sensitized solar cells. Dyes Pigm. 2010, 87, 249-256. [CrossRef]

25. Liu, J.; Luo, Y.; Li, L.; Wang, G.; Wang, X.; Chen, Y.; Liu, B. Photovoltaic Performance of 4,8-Bis(2'-ethylhexylthiophene)thieno[2,3f]benzofuran-Based Dyes Fabricated with Different Donors in Dye-Sensitized Solar Cells. ACS Omega 2020, 5, 12440-12450. [CrossRef]

26. Li, C.T.; Wu, F.L.; Liang, C.J.; Ho, K.C.; Lin, J.T. Effective suppression of interfacial charge recombination by a 12-crown-4 substituent on a double-anchored organic sensitizer and rotating disk electrochemical evidence. J. Mater. Chem. 2017, 5, 7586-7594. [CrossRef]

27. Abbotto, A.; Manfredi, N.; Marinzi, C.; De Angelis, F.; Mosconi, E.; Yum, J.H.; Zhang, X.; Nazeeruddin, M.K.; Grätzel, M. Di-branched di-anchoring organic dyes for dye-sensitized solar cells. Energy Environ. Sci. 2009, 2, 1094-1101. [CrossRef]

28. Kumar, D.; Wong, K.T. Organic dianchor dyes for dye-sensitized solar cells. Mater. Today Energy 2017, 5, 243-279. [CrossRef]

29. Seo, K.D.; You, B.S.; Choi, I.T.; Ju, M.J.; You, M.; Kang, H.S.; Kim, H.K. Dual-channel anchorable organic dyes with well-defined structures for highly efficient dye-sensitized solar cells. J. Mater. Chem. A 2013, 1, 9947-9953. [CrossRef]

30. Seo, K.D.; You, B.S.; Choi, I.T.; Ju, M.J.; You, M.; Kang, H.S.; Kim, H.K. Dye-Sensitized Solar Cells based on Organic Dual-Channel Anchorable Dyes with Well-Defined Core Bridge Structures. ChemSusChem 2013, 6, 2069-2073. [CrossRef]

31. Manfredi, N.; Cecconi, B.; Abboto, A. Multi-Branched Multi-Anchoring Metal-Free Dyes for Dye-Sensitized Solar Cells. Eur. J. Org. Chem. 2014, 2014, 7069-7086. [CrossRef]

32. Lo, C.Y.; Kumar, D.; Chou, S.H.; Chen, C.H.; Tsai, C.H.; Liu, S.H.; Chou, P.T.; Wong, K.T. Highly Twisted Dianchoring D- $\pi-A$ Sensitizers for Efficient Dye-Sensitized Solar Cells. ACS Appl. Mater. Interfaces 2016, 8, 27832-27842. [CrossRef]

33. Lee, Y.H.; Yun, H.J.; Choi, S.K.; Yang, Y.S.; Park, T.; Ahn, K.S.; Suresh, T.; Kim, J.H. Triphenylamine-based tri-anchoring organic dye with enhanced electron lifetime and long-term stability for dye sensitized solar cells. Synth. Met. 2016, 217, 248-255. [CrossRef]

34. Tan, H.; Pan, C.; Wang, G.; Wu, Y.; Zhang, Y.; Zou, Y.; Yu, G.; Zhang, M. Phenoxazine-based organic dyes with different chromophores for dye-sensitized solar cells. Org. Electron. 2013, 14, 2795-2801. [CrossRef]

35. Yook, K.S.; Lee, J. Organic materials for deep blue phosphorescent organic light-emitting diodes. Adv. Mater. 2012, 24, 3169-3190. [CrossRef]

36. Huang, Z.S.; Zang, X.F.; Hua, T.; Wang, L.; Meier, H.; Cao, D. 2,3-Dipentyldithieno[3,2-f:2',3'-h]quinoxaline-Based Organic Dyes for Efficient Dye-Sensitized Solar Cells: Effect of $\pi$-Bridges and Electron Donors on Solar Cell Performance. ACS Appl. Mater. Interfaces 2015, 7, 20418-20429. [CrossRef]

37. Kim, B.G.; Chung, K.; Kim, J. Molecular Design Principle of All-organic Dyes for Dye-Sensitized Solar Cells. Chem. Eur. J. 2013, 19, 5220-5230. [CrossRef]

38. Hara, K.; Sato, T.; Katoh, R.; Furube, A.; Ohga, Y.; Shinpo, A.; Suga, S.; Sayama, K.; Sugihara, H.; Arakawa, H. Molecular Design of Coumarin Dyes for Efficient Dye-Sensitized Solar Cells. J. Phys. Chem. B 2003, 107, 597-606. [CrossRef]

39. Hagfeldt, A.; Grätzel, M. Light-Induced Redox Reactions in Nanocrystalline Systems. Chem. Rev. 1995, 95, 49-68. [CrossRef]

40. Cisneros, R.; Beley, M.; Fauvarque, J.F.; Lapicque, F. Investigation of electron transfer processes involved in DSSC's by wavelength dependent electrochemical impedance spectroscopy ( $\lambda$-EIS). Electrochim. Acta 2015, 171, 49-58. [CrossRef]

41. Rahman, M.; Nath, N.C.D.; Lee, J.J. Electrochemical Impedance Spectroscopic Analysis of Sensitization-Based Solar Cells. Isr. J. Chem. 2015, 55, 990-1001. [CrossRef] 
42. Zainudin, S.N.F.; Abdullah, H.; Markom, M. Electrochemical studies of tin oxide based-dye-sensitized solar cell (DSSC): A review. J. Mater. Sci. Mater. Electron. 2019, 30, 5342-5356. [CrossRef]

43. Pignanelli, F.; Fernández-Werner, L.; Romero, M.; Mombrú, D.; Tumelero, M.A.; Pasa, A.; German, E.; Faccio, R.; Mombrú, A.W. Hydrogen titanate nanotubes for dye sensitized solar cells applications: Experimental and theoretical study. Mater. Res. Bull. 2018, 106, 40-48. [CrossRef] 